\title{
Evaluation of Respiratory Function in Patients with Epileptic Seizures
}

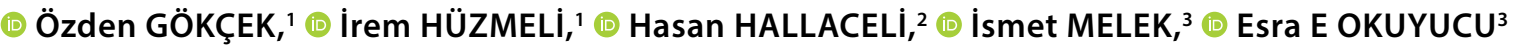

'Department of Physical Theraphy and Rehabilitation, Hatay Mustafa Kemal University Tayfur Ata Sökmen Faculty of Medicine, Hatay, Turkey

${ }^{2}$ Department of Orthopedics and Traumatology, Hatay Mustafa Kemal University Tayfur Ata Sökmen Faculty of Medicine, Hatay, Turkey

${ }^{3}$ Department of Neurology, Hatay Mustafa Kemal University Tayfur Ata Sökmen Faculty of Medicine, Hatay, Turkey

\begin{abstract}
Objectives: Respiratory problems increase the number of epileptic seizures in individuals with epileptic seizures. This study aimed to determine the relationship between the number of seizures, sleep quality, and respiratory problems by evaluating the changes in respiratory parameters of epileptic patients.

Methods: Thirty individuals aged 18-40 years with generalized epilepsy were included in the study. Demographic data, number of seizures per week, pulse and blood pressure measurements, age of seizures, and body mass index were recorded. Dyspnea with mMRC; pulmonary function test; level of physical activity (PA) with International physical activity assessment survey (IPAQ); mouth pressure measuring device with respiratory muscle strength; and sleep quality with Pittsburgh Sleep Quality Index (PSQI) were evaluated.

Results: Thirty patients with epileptic seizures (mean age: $26.56 \pm 6.64$ years) were included in the study. The mean; \% maximal inspiratory pressure (MIP) 67.44, \%Maximal expiratory pressure (MEP) 35.14, MIP 70.47, and MEP $62.24 \mathrm{cmH}_{2} \mathrm{O}$ were found. The forced expiratory volumes/ forced vital capacity (FEV $/ F V C)(41.01 \%)$ and $\mathrm{FEV}_{1}(62.50 \% ; 2.56 \mathrm{~L})$ was found lower than the standards. The positive correlation between the MEP, MIP, FEV $(L)$, and severe PA was found. FVC with sitting, FEV1 (L) with moderate PA, and FEV $/$ FVC (\%) with PSQI, sitting with educational status were positively correlated $(p<0.05)$. There was a negative correlation between the $\%$ MIP and a systolic blood pressure; MIP, MEP $(\%$ and $\mathrm{cmH} 2 \mathrm{O})$ with diastolic blood pressure $(\mathrm{p}<0.05)$, and a positive correlation between the \%MEP and $\mathrm{SpO}_{2}(\mathrm{p}<0.05)$.

Conclusion: As a result, respiratory function, $\mathrm{PA}$, and the sleep quality of individuals with epilepsy were affected. Respiratory muscle training, PA programs, and behavioral changes should be added to the medical treatment programs of these individuals.
\end{abstract}

Keywords: Generalized epilepsy; international physical activity question; Pittsburgh sleep quality index; pulmonary function test.

Cite this article as: Gökçek Ö, Hüzmeli I, Hallaceli H, Melek I, Okuyucu EE. Evaluation of Respiratory Function in Patients with Epileptic Seizures. Epilepsi 2021;27:171-176.

\section{Introduction}

Epilepsy is defined as the sudden, abnormal, and hypersynchronous discharge of the neuron population that has a specific function in the central nervous system. ${ }^{[1]}$ An epileptic seizure is caused by neuronal hyperexcitability of the nerve cells in the brain. Neurons show great sensitivity to $\mathrm{pH}$ change of the interstitial fluid, alkalose neuron excitability greatly increases. Increased arterial $\mathrm{pH}$ with excessive respiratory activity may cause epileptic seizures in individuals

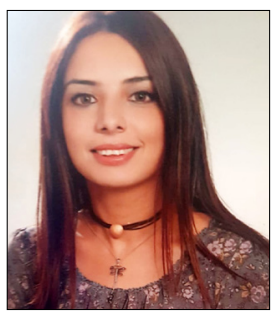

Corresponding author Özden GÖKÇEK, M.D.

e-mail ozdencanbay@hotmail.com

Received 16.02.2021

Accepted 19.04.2021

Online date 30.07.2021

Content of this journal is licensed under a Creative Commons Attribution-NonCommercial 4.0 International License.

Özden GÖKÇEK, M.D. with a tendency for epileptic convulsions. ${ }^{[2]}$ Epilepsy is one of the most common neurological diseases, with an average of $4-10 / 1000 .^{[3]}$ Epileptic seizures disrupt the structure of sleep. In patients with epilepsy, REM breaks up during sleep and increases wakening up during sleep. ${ }^{[4]}$

The literature shows that physical activity (PA) is beneficial in the quality of life and multiple health problems in epileptic patients. ${ }^{[5]}$

This study aimed to determine the relationship between the number of seizures, sleep quality, and respiratory problems by evaluating the changes in respiratory parameters of epileptic patients.

\section{Materials and Methods}

Thirty generalized epilepsy patients between the ages of 18 and 40 year old who were admitted in the study. The exclusion criteria pregnant patients, patients with severe mental disabilities, and patients with severe heart problems 


\section{Epileptik Nöbeti Olan Hastalarda Solunum Fonksiyonunun Değerlendirilmesi}

\section{Öz}

Amaç: Solunum problemleri, epileptik nöbeti olan kişilerde epileptik nöbet sayısını artırmaktadır. Bu çalışma, epilepsili hastaların solunum parametrelerindeki değişiklikleri değerlendirerek nöbet sayısı, uyku kalitesi ve solunum sorunları arasındaki ilişkiyi belirlemeyi amaçlamaktadır. Gereç ve Yöntem: Epilepsi tanısı almış 18-40 yaş aralığında 30 birey çalışmaya dahil edildi. Epilepsi hastalarının demografik veriler, haftalık nöbet sayısı, kullanılan ilaç, nöbet yaşı ve vücut kitle indeksi kaydedildi. MMRC ile dispne; solunum fonksiyon testi; Uluslararası fiziksel aktivite değerlendirme anketi (IPAQ) ile fiziksel aktivite seviyesi (PA); Pittsburgh Uyku Kalitesi İndeksi (PUQI) ile uyku kalitesi ve ağız basıncı ölçüm cihazı solunum kas gücü değerlendirildi. Çalışma için etik kurul onayı alındı.

Bulgular: Epileptik nöbeti olan 30 hasta (ortalama yaş: $26.56 \pm 6.64$ yıl) çalışmaya dahil edildi. Ortalama; \% MIP 67.44, \% MEP 35.14, MIP 70.47 ve MEP $62.24 \mathrm{cmH}_{2} \mathrm{O}$ bulundu. FEV $/$ FVC (\%41.01) ve FEV1 (\%62.50; $\left.2.56 \mathrm{~L}\right)$ standartların altında bulundu. MEP, MIP, FEV $(\mathrm{L})$ ve şiddetli PA arasında pozitif korelasyon bulundu. Oturarak FVC, orta düzeyde PA ile $F_{1}(L)$ ve PSQI ile $F E V_{1} / F V C(\%)$, oturma ile eğitim durumu arasında pozitif korelasyon vardı $(\mathrm{p}<0.05)$. \% MIP ile sistolik kan basıncı arasında negatif bir korelasyon vardı; MIP, MEP (\% ve $\mathrm{cmH}_{2} \mathrm{O}$ ) ile diyastolik kan basıncı $(p<0.05)$ ve $\%$ MEP ve $\mathrm{SpO}_{2}$ arasında pozitif bir korelasyon $(p<0.05)$.

Sonuç: Sonuç olarak epilepsili bireylerin solunum fonksiyonları, fiziksel aktiviteleri ve uyku kalitesi etkilenmiştir. Bu bireylerin tıbbi tedavi programlarına solunum kas eğitimi ve fiziksel aktivite programları da eklenmelidir.

Anahtar sözcükler: Epilepsi; jeneralize nöbet; Pittsburgh uyku kalitesi ölçeği; solunum fonksiyon testi; uluslararası fiziksel aktivite soruları.

were excluded from the study. The study was approved by the Ethics Committee of the University $(\mathrm{No}=2017 / 82)$ and performed in accordance with the Declaration of Helsinki. Written informed consent was obtained from all patients to participate in the study. Patients with epilepsy who agreed to participate in the study were evaluated. Demographic information of the individuals; weekly seizure number, pulse, and blood pressure measurements, seizure age, and body mass index were recorded.

Shortness of breath was measured with the Modified Medical Research Council (mMRC) scale, oxygen saturation $\left(\mathrm{SpO}_{2}\right)$ was measured with a pulse-oximeter, pulmonary function was measured with the pulmonary function test, $P A$ was measured with the International Physical Activity Assessment Questionnaire (IPAQ), respiratory muscle strength was measured with a mouth pressure measurement device, and sleep quality was evaluated with the Pittsburgh Sleep Quality Index (PSQI).

Hatay Mustafa Kemal University Scientific Research Project (no:18.M.030) supported the current study.

Pulmonary function test- Pulmonary function tests were performed using the ATS standards with a volume sensitive spirobank Italy (MIR) spirometer that measured using a dry system infrared interruption method. ${ }^{[6]}$ In the pulmonary function test, forced expiratory volumes $\left(\mathrm{FEV}_{1}\right)$, forced vital capacity (FVC), and $\mathrm{FEV}_{1} / \mathrm{FVC}$ were measured in the first second.

Respiratory muscle strength- Respiratory muscle strength was measured according to the Maximal inspiratory pres- sure (MIP) and Maximal expiratory pressure (MEP) ATS/ERS criteria using a portable electronic mouth pressure device. ${ }^{[7]}$

IPAQ- According to the IPAQ, all activities should be performed at least $10 \mathrm{~min}$ at a time. Multiply the minutes, days and metabolic equivalent minutes (MET) to obtain a score as "MET-minutes/week." PA levels were physically inactive ( $<600 \mathrm{MET}-\mathrm{min} /$ week), low PA (600-3000), and sufficient PA (health-beneficial) (>3000 MET-min/week). ${ }^{[8]}$

mMRC scale- The mMRC scale was used to assess the shortness of breath during daily life activities. Patients choose the expression that best describes the perceived shortness of breath among the five expressions of dyspnea; it is scored between 0 and 4 . Shortness of breath is exacerbated from 0 to $4 .{ }^{[9]}$

PSQI- The PSQI is a 19-item scale that assesses the sleep quality and impairment in the past month. It consists of 24 questions. Questions are scored between 0 and 3. The total score ranges from 0 to 21 . A score of 5 or less indicates good sleep quality, a score $>5$ indicate poor sleep quality. ${ }^{[10]}$

Statistical analysis- The SPSS version 20.0 statistical program was used in the data analysis of our study. Data were expressed as means \pm standard deviation. In the study, the Pearson Correlation Test condition was used in cases of parametric conditions and the Spearman Correlation Test condition was used in cases where the parametric conditions were not met. Significant coefficients ranged from 0 to 0.2 (very weak), from 0.21 to 0.4 (weak), from 0.41 to 0.6 (moderate intensity), from 0.61 to 0.8 (high), and from 0.81 to 1 was determined to be (too high). 


\section{Results}

Thirty patients diagnosed with epilepsy (mean age: $26.56 \pm 6.64$ years) were included in the study. In the study, the average of the individuals participated wa found to be MIP\% 67.44, the MEP\% 35.14, the MIP 70.47, and the MEP 62.24. In the pulmonary function test, $\mathrm{FEV}_{1} / \mathrm{FVC}(41.01 \%)$ and $\mathrm{FEV}_{1}$ (mean 62.50\%; mean 2.56L) were found to be lower than the standards (Table 1 ).

$\operatorname{MEP}(r=0.417 \mathrm{p}=0.022), \operatorname{MIP}(r=0.452 \mathrm{p}=0.012), \mathrm{FEV}_{1}(r=0.447$ $\mathrm{p}=0.013)$, and moderate PA between severe PA, FVC $(L, \%)$ of the sitting $(r=0.367 p=0.046, r=0.406 p=0.026)$ with a low moderately positive direction, $\mathrm{FEV}_{1}(\mathrm{~L})$ with moderate $\mathrm{PA}$ $(r=0.447 \mathrm{p}=0.013)$ moderately positive, and $\mathrm{FEV}_{1} / \mathrm{FVC} \%$ and sleep quality $(r=0.410 \mathrm{p}=0.027)$ (Table 2 ).

There was a negative correlation between the profession of epileptic individuals and MIP ( $r=-0.549 \mathrm{p}=0.002), \mathrm{MIP} \%$ $(r=-0.449 \mathrm{p}=0.013)$, and MEP\% $(r=-0.372 \mathrm{p}=0.043)$ (Table
3). The occupations were $33.7 \%$ for housewives, $23.3 \%$ for unemployed, $23.3 \%$ for self-employed, $16.7 \%$ for students, and $5.5 \%$ for farmers.

In the IPAQ sitting, there was a positive correlation with educational status $(r=0.591 \mathrm{p}=0.001)$, a negative correlation with occupation $(r=-0.440 p=0.015)$. IPAQ moderate PA was negatively correlated with the number of seizures $(r=0.385 p=0.035)$, and severe PA level was negatively correlated with occupation $(r=-0.467 p=0.009)$. There was a moderate positive correlation between occupation and dyspnea $(r=0.474 \mathrm{p}=0.009)$ and sleep quality $(r=0.474$ $\mathrm{p}=0.009$ ) (Table 4).

There was a negative correlation between diastolic blood pressure and MIP ( $r=-0.534 \mathrm{p}=0.002)$, \%MIP $(r=-0.675$ $\mathrm{p}=0.000)$, MEP ( $r=-0.367 \mathrm{p}=0.046)$, and \%MEP $(\mathrm{r}=-0.463$ $\mathrm{p}=0.010)$. There was a negative correlation between MIP\% and cytolic blood pressure $(r=-0.420 \mathrm{p}=0.021)$. There was

Table 1. Group descriptive statistics

\begin{tabular}{|c|c|c|c|c|}
\hline & $\begin{array}{c}\text { Average } \\
(n=30)\end{array}$ & $\begin{array}{l}\text { Standard deviation } \\
\qquad(\mathrm{n}=30)\end{array}$ & $\begin{array}{l}\text { Minimum } \\
(n=30)\end{array}$ & $\begin{array}{l}\text { Maximum } \\
(\mathrm{n}=30)\end{array}$ \\
\hline Age (year) & 26.56 & 6.64 & 18 & 40 \\
\hline Height (cm) & 165.7 & 11.92 & 120 & 181 \\
\hline Weight (kg) & 70.30 & 12.83 & 52 & 103 \\
\hline 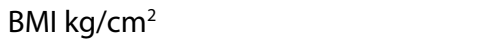 & 25.67 & 4.22 & 18.56 & 36.11 \\
\hline $\mathrm{SpO}_{2} \%$ & 97.46 & 1.40 & 95 & 100 \\
\hline Heart rate (beats/min) & 83.30 & 11.01 & 57 & 100 \\
\hline Respiratory frequency (breaths/min) & 20.80 & 3.73 & 12 & 28 \\
\hline Systolic blood pressure (mm Hg) & 116,66 & 17,23 & 90 & 160 \\
\hline Diastolic blood pressure (mm Hg) & 76 & 9,5 & 50 & 90 \\
\hline $\mathrm{MIP}\left(\mathrm{cmH}_{2} \mathrm{O}\right)$ & 70.47 & 30.82 & 29 & 159 \\
\hline \%MIP (\%) & 67.44 & 29.38 & 23.93 & 127.43 \\
\hline $\operatorname{MEP}\left(\mathrm{cmH}_{2} \mathrm{O}\right)$ & 62.24 & 24.44 & 32 & 117 \\
\hline$\%$ MEP (\%) & 35.14 & 13.10 & 14.6 & 71.91 \\
\hline $\mathrm{FEV}_{1}(\mathrm{~L})$ & 2.56 & 1.37 & 0.07 & 4.57 \\
\hline $\mathrm{FEV}_{1}(\%)$ & 62.50 & 32.36 & 2 & 114 \\
\hline FVC (L) & 3.28 & 1.28 & 0.1 & 2.4 \\
\hline FVC (\%) & 73.7 & 26.53 & 4 & 116 \\
\hline $\mathrm{FEV}_{1} / \mathrm{FVC}$ & 41.01 & 42.28 & 0.03 & 89.80 \\
\hline PEF (L) & 5.78 & 2.97 & 0.6 & 13 \\
\hline PEF (\%) & 40.75 & 21.53 & 0.5 & 80 \\
\hline $\mathrm{mMRC}$ & 0.79 & 0.77 & 0 & 3 \\
\hline BORG & 1.29 & 1.19 & 0 & 4 \\
\hline PSQI & 4.24 & 3.60 & 0 & 14 \\
\hline IPAQ total & 2033.6 & 2619.4 & 0 & 10422 \\
\hline
\end{tabular}

Sperman correlation $\mathrm{p}<0.05$. BMI: Body mass index; $\mathrm{SpO}_{2}$ : Oxygen saturation; MIP: Maximal inspiratory pressure; MEP: Maximal expiratory pressure; $\mathrm{FEV}_{1}$ : Forced expiratory volumes; FVC: Forced vital capacity; mMRC: Modified medical research council; PSQI: Pittsburgh sleep quality index; IPAQ: International physical activity assessment survey. 
Table 2. Relationship between respiratory parameters, sleep quality, physical activity, and dyspnea

\begin{tabular}{|c|c|c|c|c|c|c|c|c|}
\hline & & IPAQ sitting & IPAQ walking & IPAQ moderate & IPAQ severe & IPAQ total & $\mathrm{mMRC}$ & PSQI \\
\hline \multirow[t]{2}{*}{ MIP } & $r$ & 0.171 & 0.093 & 0.298 & 0.452 & 0.289 & -0.359 & 0.094 \\
\hline & $\mathrm{p}$ & 0.366 & 0.623 & 0.110 & 0.012 & 0.121 & 0.056 & 0.626 \\
\hline \multirow[t]{2}{*}{$\%$ MIP } & $r$ & 0.189 & 0.074 & 0.268 & 0.245 & 0.205 & -0.347 & 0.104 \\
\hline & $\mathrm{p}$ & 0.317 & 0.698 & 0.152 & 0.191 & 0.277 & 0.066 & 0.590 \\
\hline \multirow[t]{2}{*}{ MEP } & $r$ & 0.141 & 0.094 & 0.119 & 0.417 & 0.216 & -0.028 & 0.158 \\
\hline & $\mathrm{p}$ & 0.459 & 0.619 & 0.530 & 0.022 & 0.252 & 0.886 & 0.413 \\
\hline \multirow[t]{2}{*}{$\%$ MEP } & $r$ & 0.279 & 0.014 & 0.099 & 0.357 & 0.154 & -0.224 & -0.082 \\
\hline & $\mathrm{p}$ & 0.136 & 0.939 & 0.602 & 0.053 & 0.416 & 0.242 & 0.671 \\
\hline \multirow[t]{2}{*}{$\mathrm{FEV}_{1}(\mathrm{~L})$} & $r$ & 0.316 & -0.014 & 0.351 & 0.447 & 0.182 & -0.120 & 0.170 \\
\hline & $\mathrm{p}$ & 0.089 & 0.943 & 0.057 & 0.013 & 0.337 & 0.534 & 0.378 \\
\hline \multirow[t]{2}{*}{$\mathrm{FEV}_{1}(\%)$} & $r$ & 0.280 & 0.119 & 0.207 & 0.257 & 0.125 & -0.160 & 0.272 \\
\hline & $\mathrm{p}$ & 0.134 & 0.532 & 0.271 & 0.170 & 0.510 & 0.480 & 0.153 \\
\hline \multirow[t]{2}{*}{ FVC (L) } & $r$ & 0.367 & 0.044 & 0.434 & 0.262 & -0.129 & 0.129 & 0.115 \\
\hline & $\mathrm{p}$ & 0.046 & 0.818 & 0.016 & 0.162 & 0.504 & 0.504 & 0.554 \\
\hline \multirow[t]{2}{*}{ FVC (\%) } & $r$ & 0.406 & 0.151 & 0.079 & 0.281 & 0.232 & -0.121 & 0.168 \\
\hline & $\mathrm{p}$ & 0.026 & 0.425 & 0.677 & 0.132 & 0.217 & 0.532 & 0.385 \\
\hline \multirow[t]{2}{*}{$\mathrm{FEV}_{1} / \mathrm{FVC}(\mathrm{L})$} & $r$ & 0.318 & 0.076 & 0.213 & 0.071 & 0.087 & -0.011 & 0.288 \\
\hline & $\mathrm{p}$ & 0.087 & 0.691 & 0.259 & 0.710 & 0.648 & 0.953 & 0.129 \\
\hline \multirow[t]{2}{*}{$\mathrm{FEV}_{1} / \mathrm{FVC}(\%)$} & $r$ & 0.067 & -0.058 & 0.311 & 0.157 & -0.043 & -0.085 & 0.410 \\
\hline & $p$ & 0.725 & 0.763 & 0.094 & 0.408 & 0.823 & 0.663 & 0.027 \\
\hline \multirow[t]{2}{*}{ PEF (L) } & $r$ & 0.330 & 0.162 & -0.072 & 0.210 & 0.146 & 0.083 & 0.202 \\
\hline & $\mathrm{p}$ & 0.075 & 0.392 & 0.704 & 0.264 & 0.443 & 0.668 & 0.293 \\
\hline \multirow[t]{2}{*}{ PEF (\%) } & $r$ & 0.169 & -0.075 & 0.112 & 0.304 & -0.077 & -0.042 & 0.230 \\
\hline & $\mathrm{p}$ & 0.373 & 0.695 & 0.556 & 0.102 & 0.688 & 0.827 & 0.230 \\
\hline
\end{tabular}

Spearman correlation p<0.05. MIP: Maximal inspiratory pressure; MEP: Maximal expiratory pressure; FEV : Forced expiratory volumes; FVC: Forced vital capacity.

Table 3. Relationship between respiratory muscle strength, and occupation

\begin{tabular}{cccccccccccc}
\hline & & MIP & \%MIP & MEP & \%MEP & FEV $_{1}(\mathrm{~L})$ & FEV $_{1}(\%)$ & FVC (L) & FVC (\%) & FEV $/$ FVC (L) & PEF (L) \\
\hline Occupation & $\mathrm{r}$ & -0.549 & -0.449 & -0.347 & -0.372 & -0.158 & -0.156 & -0.143 & 0.209 & -0.144 & -0.011 \\
& $\mathrm{p}$ & 0.002 & 0.013 & 0.061 & 0.043 & 0.403 & 0.411 & 0.452 & 0.269 & 0.447 & 0.953 \\
\hline
\end{tabular}

Sperman correlation p<0.05. MIP: Maximal inspiratory pressure; MEP: Maximal expiratory pressure; FEV; Forced expiratory volumes; FVC: Forced vital capacity.

Table 4. Relationship between descriptive information and physical activity, sleep quality and dyspnea

\begin{tabular}{lcccccccc}
\hline & & IPAQ sitting & IPAQ walking & IPAQ moderate & IPAQ severe & IPAQ total & mMRC & PSQI \\
\hline Age (year) & $\mathrm{r}$ & -0.265 & 0.360 & -0.105 & -0.460 & 0.146 & 0.322 & 0.252 \\
& $\mathrm{p}$ & 0.156 & 0.050 & 0.582 & 0.010 & 0.441 & 0.089 & 0.188 \\
Education status & $\mathrm{r}$ & 0.591 & -0.176 & 0.120 & 0.341 & -0.045 & -0.105 & -0.168 \\
& $\mathrm{p}$ & 0.001 & 0.352 & 0.528 & 0.065 & 0.815 & 0.586 & 0.383 \\
Occupation & $\mathrm{r}$ & -0.440 & -0.179 & -0.038 & -0.467 & -0.351 & 0.474 & 0.474 \\
& $\mathrm{p}$ & 0.015 & 0.344 & 0.841 & 0.009 & 0.057 & 0.009 & 0.009 \\
Seizure number & $\mathrm{r}$ & 0.076 & 0.033 & 0.385 & -0.119 & 0.205 & -0.029 & -0.154 \\
& $\mathrm{p}$ & 0.689 & 0.862 & 0.035 & 0.530 & 0.278 & 0.880 & 0.426 \\
\hline
\end{tabular}

Sperman correlation p<0.05. IPAQ: International physical activity assessment survey; mMRC: Modified medical research council; PSQI: Pittsburgh sleep quality index. 
Table 5. The relationship between respiratory muscle strength and blood pressure

\begin{tabular}{llccc}
\hline & & Systolic & Diastolic & $\mathrm{SpO}_{2}$ \\
\hline MIP & $\mathrm{r}$ & -0.270 & -0.534 & 0.222 \\
& $\mathrm{p}$ & 0.150 & 0.002 & 0.239 \\
$\%$ MIP & $\mathrm{r}$ & -0.420 & -0.675 & 0.333 \\
& $\mathrm{p}$ & 0.021 & 0.0001 & 0.072 \\
MEP & $\mathrm{r}$ & -0.88 & -0.367 & 0.150 \\
& $\mathrm{p}$ & 0.645 & 0.046 & 0.428 \\
$\%$ MEP & $\mathrm{r}$ & -0.188 & -0.463 & 0.372 \\
& $\mathrm{p}$ & 0.321 & 0.010 & 0.043 \\
\hline
\end{tabular}

Sperman correlation $\mathrm{p}<0.05 . \mathrm{SpO}_{2}$ : Oxygen saturation; MIP: Maximal inspiratory pressure; MEP: Maximal expiratory pressure.

a positive correlation between the $\mathrm{MEP} \%$ and $\mathrm{SpO}_{2}$ value $(r=0.372 \mathrm{p}=0.043)$ (Table 5).

\section{Discussion}

This study aimed to determine the relationship between the number of seizures, sleep quality, and respiratory problems by evaluating the changes in respiratory parameters of epileptic patients.

It is stated in the literature that epileptic patients have a sedentary life, and their participation in PA is low. ${ }^{[1]}$ In our study, it was found that moderate PA status positively correlated with the epilepsy seizure numbers. Epilepsy seizure numbers affects the PA.

The social roles of epileptic patients are limited due to seizure anxiety; thus, these individuals miss opportunities. Consequently, occupational and social success and the functionality of epileptic patients are lower. Evidence to recent suggests that PA reduces the occurrence of epileptic form discharges in children and adults with epilepsy. Hence, active epileptic people are affected less than the inactive epileptic individuals. ${ }^{[12]}$ In our study, it was found that occupational status was negatively correlated with PA and positively blinded with dyspnea and sleep quality.

An epileptic seizure is caused by increased excitability (neuronal hyperexcitability) of the nerve cells in the brain and may occur due to various reasons. Epileptic seizures may be associated with autonomic dysregulation, such as variability in blood pressure and heart rate. ${ }^{[13]}$ In our study, it was found that the mean values of heart rate, blood pressure, respiratory frequency, and oxygen saturation, which we measured instantaneously, were in normal standards although they differed individually. According to the results of our study, autonomic regulation caused a change in the
MIP\% in epileptic patients. MEP\% was also associated with diastolic blood pressure and oxygen saturation.

Sleep failure is common in epileptic patients. In the study by Malow et al. ${ }^{[14]} 63$ epileptic patients who underwent polysomnography, the majority $(78 \%)$ were named as having obstructive sleep apnea; the remaining 19\% had excessive sleepiness and night seizures. Hypoxia and sleep fragmentation due to obstructive sleep apnea increases seizure risk and epilepsy. ${ }^{[15]}$ Studies have shown that sleep affects seizure activity. The triggering of seizures by sleep disorders and the presence of seizures in sleep suggest the interaction of sleep and epilepsy. ${ }^{[16]}$ In our study, it was found that the number of epilepsy seizures did not affect sleep quality.

Frequent seizures may interrupt social and work activities and reduce the quality of life. Night seizures also negatively affect sleep quality. In another study, no relationship was found between the frequency of seizures and sleep disorders. ${ }^{[17]}$

Lannon and Vaughn reported poor sleep quality in 37\% of patients with epilepsy. ${ }^{[18]}$ In our study, the sleep quality of $36.7 \%$ of individuals was found to be poor. Of those with poor sleep quality, $27.3 \%$ were housewife's, $27.3 \%$ were unemployed, and $27.3 \%$ were self-employed.

OSAS may increase the risk of Sudden Unexpected Death in Epilepsy, especially in patients with refractory epilepsy, associated with respiratory, dysautonomic mechanisms, and poor seizure control. ${ }^{\left[{ }^{[9]}\right.}$ It has been reported that antiepileptic drugs facilitate apnea by reducing the reactivity of respiratory centers in the brain stem. ${ }^{[20]}$ In the literature, sleep disorder is more common in patients with generalized epilepsy. ${ }^{[21]}$

A general convulsion and respiratory dysfunction have been identified for sudden deaths in epilepsy monitor units. ${ }^{[22]}$ Early intervention can shorten the duration of a general convulsion and reduce the severity of respiratory and brain dysfunction. ${ }^{[23]}$ In our study, impairments in respiratory functions were found to standards of ATS/ERS.

Bittencou et al. ${ }^{[24]}$ found that 32 patients with an Apnea-Hypopnea Index value of 40 had a mean Pimax of $112 \mathrm{cmH}_{2} \mathrm{O}$ and a mean Pemax of $106.5 \mathrm{cmH}_{2} \mathrm{O}$ Pimax value of our patients was $70.47 \mathrm{cmH}_{2} \mathrm{O}$ and Pemax average was found to be $62.24 \mathrm{cmH}_{2} \mathrm{O}$. In contrast to this study, in our study, it was seen that the inspiratory and expiratory muscles were weak due to low oral pressure values in epileptic patients. 
Conclusion- As a result, the respiratory function, PA, and sleep quality of individuals with epilepsy are affected. Respiratory muscle training, PA programs, and behavioral changes should be added to the medical treatment programs of these individuals.

Limitation- Our study is one of the rare studies evaluating the pulmonary function, PA level and sleep status in epileptic individuals, especially in younger ones. The limitation of the study was that we did not include healthy individuals compatible with the age and gender of epileptic patients.

Acknowledgment- We thank the Hatay Mustafa Kemal University Scientific Research Project coordinator for supporting our study.

Informed Consent- Written informed consent was obtained from patients who participated in this study.

Ethics Committee Approval- This study approved by the Hatay Mustafa Kemal University Tayfur Ata Sökmen Faculty of Medicine Ethics Committee (Date: 2017, Decision No: 2017/82).

Peer-review- Externally peer-reviewed.

Authorship Contributions- Concept: Ö.G.; Design: Ö.G., H.H.; Supervision: E.E.O.; Data collection \&/or processing: Ö.G., I.H., I.M.; Analysis and/or interpretation: Ö.G., H.H.; Literature search: Ö.G.; Writing: Ö.G., I.H., E.E.O.; Critical review: I.M., H.H., E.E.O.

Conflict of interest- The authors declare that they have no conflict of interest.

Financial Disclosure: Financial support was received from Hatay Mustafa Kemal University Scientific Research Project.

\section{References}

1. Adams RD, Victor M, Ropper AH. Epilepsy and disorder of consciousness: In: Adams RD, Victor M, Ropper AH, editors. Principles of Neurology. 7th ed. NewYork: International Edition; 2001. p. 329-404.

2. Guyton AC, Hall JE. Tibbi Fizyoloji. 10th ed. W.B. Philadelphia, PA: Saunders; 2001. p. 525-6.

3. Sander JW, Shorvon SD. Epidemiology of the epilepsies. J Neurol Neurosurg Psychiatry 1996;61(5):433-43. [CrossRef]

4. Vaughn BV, Ali I. Sleep and epilepsy: Opportunities for diagnosis and treatment. Neurol Clin 2012;30(4):1249-74. [CrossRef]

5. Arida RM, Scorza FA, da Silva SG, Schachter SC, Cavalheiro EA. The potential role of physical exercise in the treatment of epilepsy. Epilepsy Behav 2010;17(4):432-5. [CrossRef]

6. American thoracic society standardization of spirometry. Am Rev Respir Dis 1987;136:1285-307. [CrossRef]

7. American Thoracic Society/European Respiratory Society. ATS/ ERS statement on respiratory muscle testing. Am J Respir Crit Care Med 2002;166(4):518-624. [CrossRef]
8. Craig $\mathrm{CL}$, Marshall $\mathrm{AL}$, Sjostrom $\mathrm{M}$, Bauman $\mathrm{AE}$, Booth $\mathrm{ML}$, Ainsworth B., et al. International physical activity questionnaire: 12-Country reliability and validity. Med Sci Sports Exerc 2003;35(8):1381-95. [CrossRef]

9. Khadawardi H, Mura M. A Simple dyspnoea scale as part of the assessment to predict outcome across chronic interstitial lung disease. Respirology 2017;22(3):501-7. [CrossRef]

10. Ağargün MY, Kara H, Anlar O.Pittsburgh Uyku Kalitesi Indeksi'nin Geçerliği ve Güvenirliği. Turk Psikiyatri Derg 1996;7(2):107-11.

11. Volpato N, Kobashigawa J, Yasuda CL, Kishimoto ST, Fernandes PT, Cendes F. Level of physical activity and aerobic capacity associate with quality of life in patients with temporal lobe epilepsy. PLoS One 2017;12(7):e0181505. [CrossRef]

12. Dimitri P, Joshi K, Jones N; Moving Medicine for Children Working Group. Moving more: physical activity and its positive effects on long term conditions in children and young people. Arch Dis Child 2020;105(11):1035-40. [CrossRef]

13. Nei M, Ho RT, Sperling MR. EKG abnormalities during partial seizures in refractory epilepsy. Epilepsia 2000;41(5):542-8. [CrossRef]

14. Malow BA, Fromes G, Aldrich MS. Usefulness of polysomnography in epilepsy patients. Neurology 1997;48:1389-94. [CrossRef]

15. Manni R, Tartara A. Evaluation of sleepiness in epilepsy. Clin Neurophysiol 2000;111(Suppl 2):111-4. [CrossRef]

16. Moser D, Pablik E, Aull-Watschinger S, Pataraia E, Wöber $\mathrm{CH}$, Seidel $S$. Depressive symptoms predict the quality of sleep in patients with partial epilepsy a combined retrospective and prospective study. Epilepsy Behav 2015;47:104-10. [CrossRef]

17. Alanis-Guevara I, Peña E, Corona T, López-Ayala T, López-Meza E, López-Gómez M. Sleep disturbances, socioeconomic status, and seizure control as main predictors of quality of life in epilepsy. Epilepsy Behav 2005;7(3):481-5. [CrossRef]

18. Lannon SL, Vaughn BV. Sleep hygiene in patients with epilepsy. Epilepsia 1997;38:227.

19. Nashef L, Ryvlin P. Sudden unexpected death in epilepsy (SUDEP): Update and reflections. Neurol Clin 2009;27(4):106374. [CrossRef]

20. Malow BA, Levy K, Maturen K, Bowes R. Obstructive sleep apnea is common in medically refractory epilepsy patients. Neurology 2000;55(7):1002-7. [CrossRef]

21. Derry CP, Duncan S. Sleep and epilepsy. Epilepsy Behav 2013;26(3):394-404. [CrossRef]

22. Kizer KW, Stegun MB. Serious reportable adverse events in healthcare. In: Advances in Patient Safety: From Research to Implementation, Programs, Tools, and Products Vol. 4. Washington, DC: US Depart-ment of Health and Human Services; 2005. p. 339-52.

23. Seyal M, Bateman LM, Li CS. Impact of periictal interventions on res-piratory dysfunction, postictal EEG suppression, and postictal immo-bility. Epilepsia 2013;54(2):377-82. [CrossRef]

24. Bittencou LR, Moura SM, Bagnato MC, Gregório LC, Tufik S, et al. Assessment of ventilatory neuromuscular drive in patients with obstructive sleep apnea. Braz J Med Biol Res 1998;31(4):50513. [CrossRef] 